\title{
Examination of an Estuarine Fish Assemblage Over an Inshore Artificial Reef
}

\author{
Kirsten A. Simonsen ${ }^{1, *}$, James H. Cowan $\mathrm{Jr}^{1}$ and Andrew J. Fischer ${ }^{2}$ \\ ${ }^{1}$ Louisiana State University, Department of Oceanography and Coastal Sciences, 2197 Energy Coast and Environment \\ Building, Louisiana State University, Baton Rouge, LA, USA 70803 \\ ${ }^{2}$ Louisiana Department of Wildlife and Fisheries, PO Box 98000, 2000 Quail Dr, Baton Rouge, LA, USA 70898
}

\begin{abstract}
The perceived value of oyster reefs as fish habitat has led to many restoration projects in areas of historically high oyster populations. This study evaluated fish usage of a limestone cobble mimic oyster reef in Barataria Bay, Louisiana, as compared to a mud-bottom reference site. Emphasis was given to species of economic and ecological importance, including spotted seatrout (Cynoscion nebulosus), Atlantic croaker (Micropogonias undulatus), and bay anchovy (Anchoa mitchilli). There were no observed differences in community structure or catch per unit effort (CPUE) between habitats, likely due to high variability in the data, though seasonal differences were observed. CPUE of spotted seatrout, Atlantic croaker, and bay anchovy did not differ between habitats. Seasonal differences in abundance were detected, with significantly higher CPUE of spotted seatrout in summer, of Atlantic croaker in spring and summer, and of bay anchovy in winter. Spotted seatrout and Atlantic croaker were both significantly larger over the artificial reef, while bay anchovy were significantly larger over the mud bottom. Spotted seatrout, a prized recreational fishing species in Louisiana, appeared to be the only species that showed higher biomass, determined by numbers and size, at the the artificial reef. This is important in the context of managing habitat enhancement projects. While the reef did not increase numbers or species richness of the overall fish community, it did have an effect on one recreationally important species. Therefore, the success of such projects is based as much on the intended purpose, as its affect on the overall community.
\end{abstract}

Keywords: Estuary, Artificial reef, Community structure, Spotted seatrout, Atlantic croaker, Bay anchovy.

\section{INTRODUCTION}

The loss of coastal marine habitats has been described as one of the greatest threats to the viability of commercial and recreational fisheries [1]. With the current shift in emphasis towards ecosystem based fisheries management, it is important to understand how habitat loss and habitat restoration will affect associated fish communities [2]. Degradation of estuarine habitats has led to numerous restoration projects throughout the United States, including the addition of artificial reef structures both to mitigate the loss of natural reef habitat and to enhance fish habitat [3-6]. The effectiveness of offshore artificial reefs in the Gulf of Mexico (GOM) to aggregate reef-associated fishes has been well documented [79]. Inshore artificial reefs in the northern GOM are generally created to replace shellfish habitat that is lost due to harvest and to enhance fisheries opportunities [10]. These reef structures may provide ecosystem functions for the associated fish assemblages that are similar to natural habitat.

\footnotetext{
*Address correspondence to this author at the Louisiana State University, Department of Oceanography and Coastal Sciences, 2197 Energy Coast and Environment Building, Louisiana State University, Baton Rouge, LA, 70803 USA; Tel: (206) 526-4163; Fax: (225) 578-6513;

Email: kirsten.a.simonsen@gmail.com
}

Current Address: National Marine Fisheries Service, Alaska Fisheries Science Center, 7600 Sand Point Way, Seattle, WA, 98115 USA
Coastal restoration projects are especially pertinent to the Louisiana Gulf coast where coastal land loss from natural and anthropogenic causes has been a long-standing problem. The majority of previous work on coastal restoration has focused on marsh habitat due to the importance of marsh edge as nursery habitat for juveniles of ecologically and economically important fish species $[11,12]$, the importance of wetlands as a storm buffer [13], restoration of ecosystem processes $[14,15]$, and the fact that $80 \%$ of the nation's wetland losses have occurred in the Louisiana coastal zone [16, 17].

Subtidal habitats, such as oyster reefs, primarily from the eastern oyster (Crassostrea virginica), are also in decline throughout the Gulf coast. In recent years a combination of factors, including disease, degrading water quality, overharvest, habitat loss, and the failure to replace oyster shell, has led to drastic declines of oyster populations [18, 19]. In addition, existing oyster reefs are lower in vertical relief due to mechanical harvest of oysters with dredges [20- 22]. The perceived value of oyster reefs as fish habitat has lead to many restoration projects in areas of historically high oyster populations including the U.S. southeast Atlantic and Gulf coasts [4]. However, due to shortages of oyster shell available for habitat enhancement, alternative materials have been utilized to provide substrate for larval oysters and other ben- 


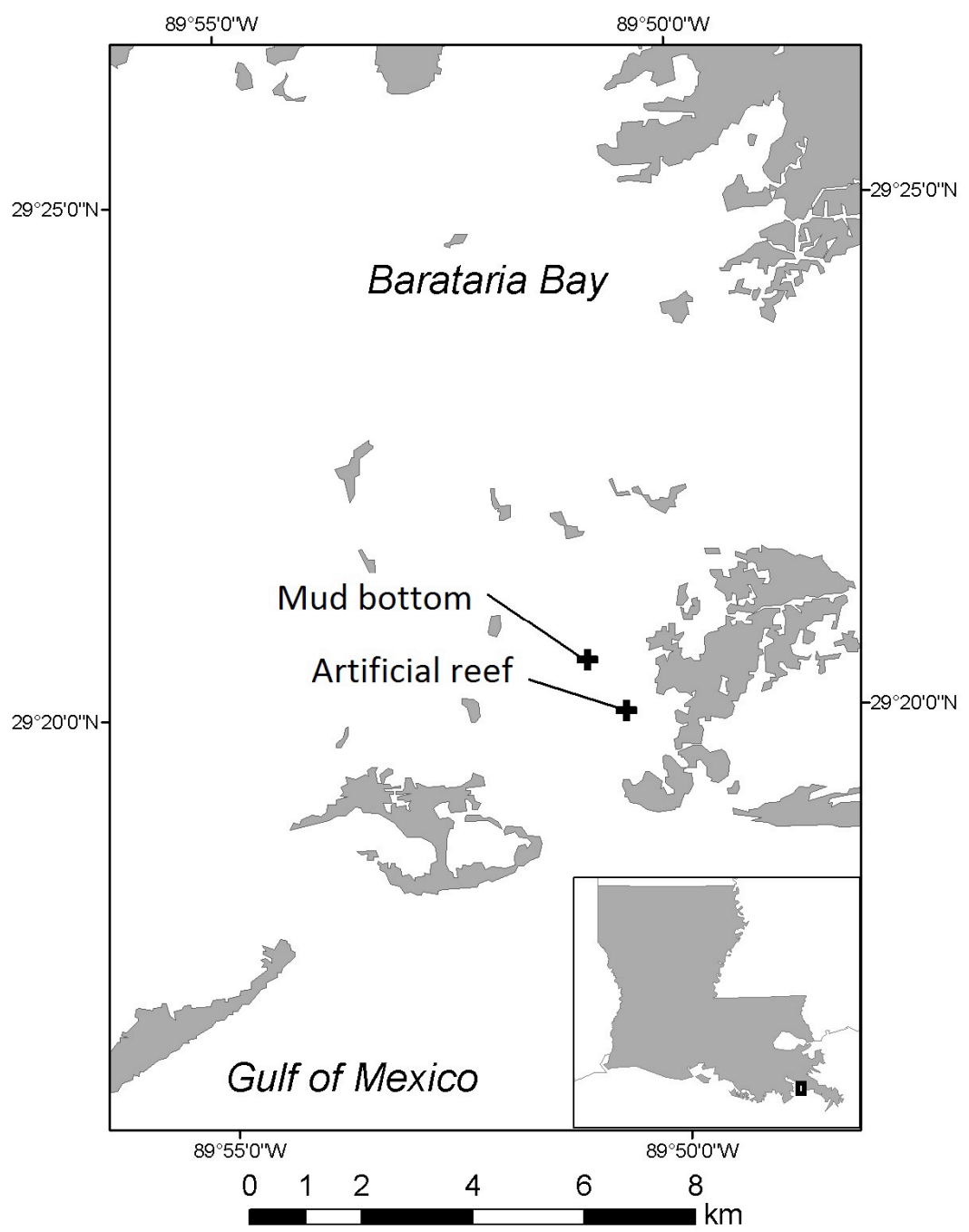

Fig. (1). Location of artificial reef and mud-bottom habitats in Bay Ronquille, Southeastern Barataria Bay, Plaquimines Parish, Louisiana.

thic invertebrates normally associated with oysters. One such material that has been found to be both cost-efficient and effective as a reef material is limestone cobble [23].

In a review of oyster reef habitat along the southeast Atlantic coast and Texas, Coen et al. [21] identified approximately 80 species of fishes that regularly associate with oyster reefs in all regions combined. Based on differences in the way fishes used reefs, they categorized species as residents, facultative residents, or transients. Resident species typically are small benthic fishes that spend most of their lives on the reef and use it for foraging, protection from predators, and reproduction [21, 24]. Facultative residents are attracted to oyster reefs, but may use other structured habitats such as submerged aquatic vegetation (SAV). Transient species, which comprise the majority of estuarine and economically important fishery species, opportunistically use different types of habitats based upon availability and need. The presence of these different classes of fishes, and how they are using the structure, can have a profound effect on how the structure is viewed and managed as fish habitat.

The purpose of this study was to evaluate the use of an artificial mimic oyster reef by estuarine fishes. The reef was constructed of limestone cobble and was designed to mimic the subtidal oyster reefs that were historically abundant in Barataria Bay, but are far more limited in spatial extent at the present time [25]. However, the reef was also designed to provide structure for sportfish species, and was never intended to enhance oyster growth in the area. It was known from the onset that oysters were unlikely to survive to maturity on the cobble reef due to high salinities and the dynamic environment of the site, though spat were not uncommon. Special emphasis is given to species of particular economic and ecological importance, including spotted seatrout $(C y$ noscion nebulosus), Atlantic croaker (Micropogonias undulatus), and bay anchovy (Anchoa mitchilli). Differences in community structure and abundance of fishes at the artificial reef site, as compared to a nearby mud-bottom mud bottom site, are described.

\section{METHODS AND MATERIALS}

\section{Study Site}

The artificial reef site (reef) is located in Bay Ronquille, a small embayment in the larger Barataria Bay, Plaquemines Parish, Louisiana (Fig. 1). Barataria Bay experiences diurnal, microtidal tides, with an average tidal flux of approximately $0.5 \mathrm{~m}$. The reef covers approximately $4,050 \mathrm{~m}^{2}$ of estuary 
bottom that previously consisted of mud and relic shell. The artificial reef was constructed in June 2004, approximately eight months before sampling began, by the Recreational Fisheries Research Institute (RFRI), in cooperation with the Louisiana Department of Wildlife and Fisheries through the Sportfish Restoration Program. Reef material consisted of number 57 limestone cobble, averaging approximately 3.8 $\mathrm{cm}$ in diameter. The mud bottom site is located approximately $1 \mathrm{~km}$ to the northwest of the reef site (Fig. 1). The mud bottom site, characterized by a mud-bottom with no relic shell or other hard substrate, was chosen due to its location with respect to the reef. The proximity of the mud bottom site to the reef allows for water conditions, including temperature, salinity, tidal movement and depth to be consistent between habitats. The habitats were therefore hypothesized to have a similar fish species composition before the addition of reef material, though unfortunately sampling of the site before reef construction was not possible. The mud bottom site is also sufficiently distant from the reef that it is not likely to be included in the foraging halo, i.e., the area around the reef subject to predation by fishes on the reef [26].

Due to the nature of the funding for reef construction for this project, only one reef site was constructed and one mud bottom site was chosen; construction of a second reef was not feasible as was established as part of a sportfish restoration effort. The authors are aware that this constitutes psudeoreplication. Therefore, replicates were conducted in time to attempt to deal with the issue of psuedoreplication. Replicates in time (termed sets in this paper) were treated as repeated measures for all statistical analyses.

\section{Water Quality}

Temperature $\left({ }^{\circ} \mathrm{C}\right)$, salinity (psu), and dissolved oxygen $(\mathrm{DO}, \mathrm{mg} / \mathrm{L})$ were measured with a YSI model $85 \AA$ at each site before any net samples were taken. To determine if water quality differed between habitats, a two-way analysis of variance (ANOVA) was run with site and season as the main effects [27]. A Tukey HSD test was used to make postANOVA comparisons $(\alpha=0.05)$.

\section{Sampling Methods}

Fishes were collected from March 2005 to February 2007, with samples collected twice per season. Seasons were defined as winter (December, January, and February), spring (March, April, and May), summer (June, July, and August) and fall (September, October, and November). Due to the inherent selectivity of fishing gears, two types were deployed to collect finfish over the habitats: gillnets and a purse seine. Gillnets were $45.7 \mathrm{~m}$ long and $1.8 \mathrm{~m}$ deep, consisting of five $9.1 \mathrm{~m}$ panels. Panels were randomly arranged with mesh sizes of $1.27,1.91,2.54,3.18$, and $3.81 \mathrm{~cm}$ square. The purse seine measured $20 \mathrm{~m}$ in length by $2 \mathrm{~m}$ in depth with a mesh size of $2 \times 2 \mathrm{~mm}$ square. Gillnets were set for one hour at each site, pulled, cleaned and reset in the same location to obtain replicate samples in time. The second gillnet set began about 20 minutes after the completion of the first, or about the time it took to sort through the haul. The purse seine was set between two vessels, one anchored and one free. Sets were accomplished by using the free boat to extend the net in a circle back to the anchored boat, where the net was pursed and all organisms removed. The purse seine set also was replicated, i.e., once before and once after the completion of gill net sampling. Fishes were bagged by gear type, net panel (for the gillnets), location (reef or mud) and set (first or second), and placed on ice. All fishes remained on ice until return to the laboratory for sorting and analysis. Those fishes that were not immediately sorted were frozen and stored upon return at $-80{ }^{\circ} \mathrm{C}$ to ensure no degradation of muscle tissue. All individual fish were identified to species and measured to both total length (TL) and standard length (SL) in $\mathrm{mm}$ and wet weight in grams.

\section{Data Analysis}

Species richness for each site was calculated as the total number of species collected over each site. The mean of species richness was calculated as the mean number of species present at each site during each season and was the sum of all species collected in both gear types. A two-way ANOVA was used to determine if the mean of species richness differed between habitats and among seasons.

Fish community composition was analyzed with PRIMER v. 6.0 (B) (Plymouth Routine in Multivariate Ecological Research; [28]) in which each one-hour gillnet set and each purse seine set is considered to be a sample. Each species is treated as a variable and data are entered as a percentage of the total catch in each sample. Data were log $(\mathrm{x}+1)$ transformed both to reduce heteroscedascity and to minimize the importance of abundant species. A Bray-Curtis similarity index was constructed from the transformed data and an analysis of similarity (ANOSIM) was run on this matrix to compare each sample to every other sample. Community structure, defined as the percentage by number of each species at each site, was compared between habitats and among seasons and their interaction with a two-way ANOSIM. Following ANOSIM, the $\log (x+1)$ transformed data were analyzed with the similarity percentages (SIMPER) option, which examines the within group (site or season) similarity as well as the between group (site and season) dissimilarity. This method permits identification of species that contribute to differences in community structure between habitats or among seasons. Separate analyses were run for each gear type based upon the assumption that direct comparisons would be compromised by gear bias. Results with p-values less than or equal to 0.05 were considered to be significantly different in PRIMER analyses.

The raw (nominal) average catch-per-unit-effort (CPUE) for all species was compared between habitats and among seasons with a two-way repeated measure ANOVA. The variable set, denoting the set number for either gillnet or purse seine set ( 1 or 2 ) was used as the repeated measure in the analysis. For CPUE analysis, effort was defined for gillnets as one 1-hour set, and for the purse seine as one circular net set. Three separate analyses of CPUE were run, including gillnet total, gillnets excluding Gulf menhaden (Brevoortia patronus), and purse seine total. CPUE was analyzed separately without Gulf menhaden to reduce biased caused by the large numbers of Gulf menhaden collected. Catch totals for focal species, including spotted seatrout, Atlantic croaker, and bay anchovy, were assessed separately to determine their 


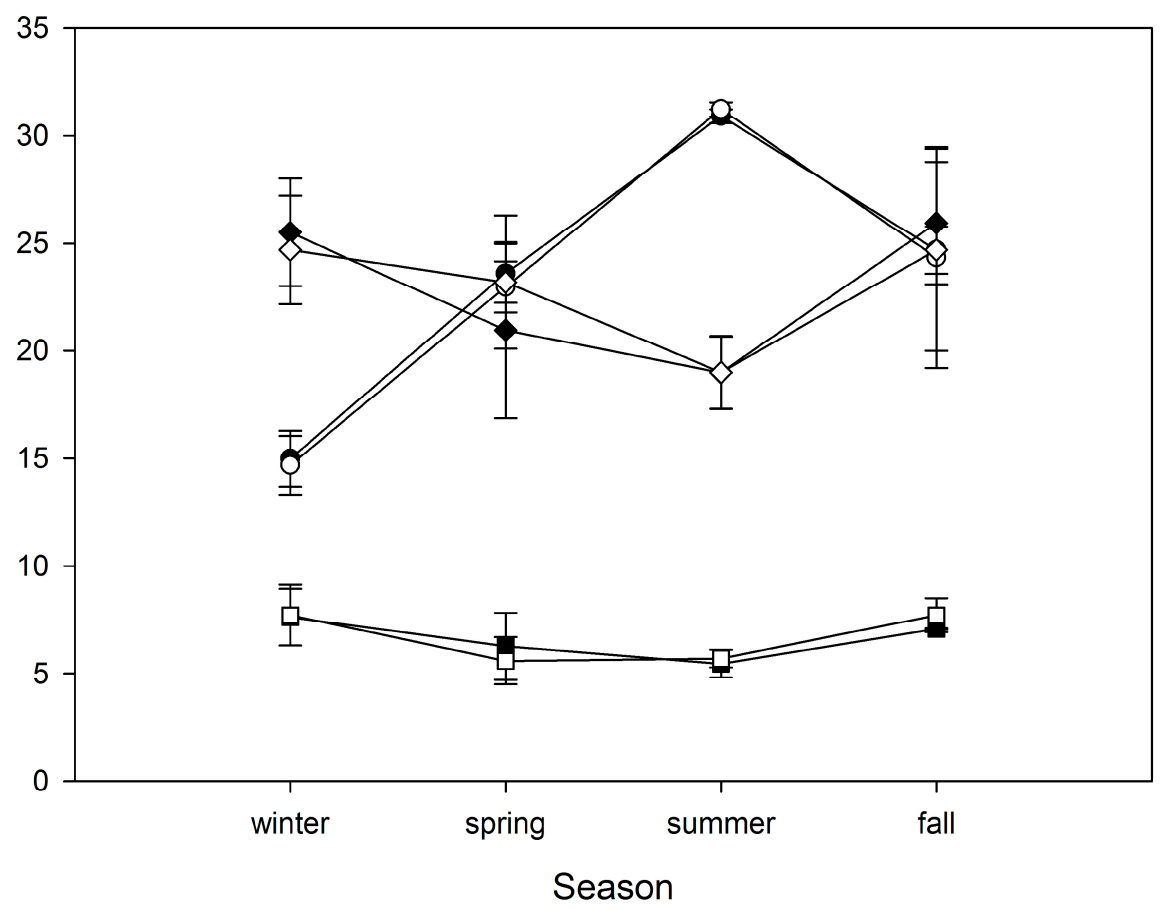

Fig. (2). Mean temperature in degrees Celsius (circle), salinity in PSU (diamond), and dissolved oxygen in mg/L (square) at artificial reef and mud-bottom habitats in Barataria Bay, Louisiana. Black circles represent artificial reef samples. White squares represent mud-bottom site samples. Standard error bars are shown.

abundance and seasonal distribution at each site. Analyses that produced significant results $(p<0.05)$ were further compared with a Tukey HSD post-hoc test.

The effects of environmental variables such as water temperature, salinity, DO and habitat on the probability of presence of spotted seatrout, Atlantic croaker, and bay anchovy were determined using logistic regression (SAS Institute 2002). The Proc Genmod procedure in SAS was used with a negative binomial link for this analysis, as this provided the best overall model fit to the data. The model was run with the variables habitat, temperature, salinity, and the interaction of habitat and temperature, excluding DO, as this reduced model provided the best overall fit.

Comparisons of the sizes of spotted seatrout $(n=89)$, Atlantic croaker $(n=410)$, and bay anchovy $(n=900)$ were conducted to determine if there were differences in the mean size of each species between habitats. A two way repeated measure ANOVA was run comparing total length (TL) and wet weight by site, season, and the interaction of site and season. Again, the variable set was used as the repeated measure in the analysis. Analyses that produced significant results $(p<0.05)$ for were further compared with a Tukey HSD post-hoc test. Size and abundance were then combined to examine if there were differences in total mean biomass of each species between habitats. Biomass was determined by summing total mass of spotted seatrout, Atlantic croaker and bay anchovy collected per net set. The total biomass was then compared between habitats. Comparisons were made with a one-way ANOVA.

\section{RESULTS}

Sampling was conducted from March 2005 to February 2007, resulting in fourteen sampling trips: four each in spring, summer, and winter and two in fall. Field research was suspended in fall 2005 due to Hurricane Katrina, which passed close to the study site and resulted in the loss of all stored fishing gear. The study site was visited approximately two months after the storm to determine the condition of the reef after the passing of the storm, and was determined to still be intact, with little dispersion of reef material. The site was deemed suitable to continue the study and sampling resumed with gillnets in January 2006 and with the purse seine in March 2006 after the gear was replaced. Because of the loss of gear during the storm, both gear types were not available during every trip. Therefore, the analysis of species richness, which was determined from the combination of nets, was limited to sampling events in which both gears were available.

Setting the purse seine prior to gillnets did not appear to affect the catch total for gillnets, likely due to the small area sampled with the purse seine as compared to the gill nets. Comparisons of gillnet total catches were made before and after the purse seine was added to the sampling protocol, and did not differ significantly in numbers or species abundance. Additionally, there were no significant differences $(\mathrm{p}>0.05$, ANOVA) between either CPUE or number of species collected between the first and second set of either the gillnets or the purse seine. This indicated that the first and second set could act as replicates in the repeated measure analysis for this study.

Mean water temperature, salinity, and DO did not differ between habitats ( $\mathrm{p}>0.05$, ANOVA). Temperatures ranged from 11.8 to $32.1{ }^{\circ} \mathrm{C}$ over the reef and from 10.8 to $32.1^{\circ} \mathrm{C}$ over the mud bottom site (Fig. 2). Salinity ranged from 8.1 to 32.7 psu over the reef and from 14.9 to 32.7 psu over the mud bottom site (Fig. 2). Dissolved oxygen ranged from 
Table 1. Total Numbers and Percentage of Total Catch for the Eleven most Commonly Collected Species at Artificial Reef and Mud Bottom Habitats in Barataria Bay, Louisiana. Total Number Collected Over each Site is also Shown. Two Species of Shrimp, white Shrimp, Litopenaeus setiferus and Brown shrimp, Farfantepenaeus aztecus, were Grouped as Penaeid Shrimp for all Analyses

\begin{tabular}{|c|c|c|c|c|}
\hline Species Total & Number Caught & Percentage of Catch & Total Number Over Artificial Reef & Total Number Over Mud Bottom \\
\hline \hline B. patronus & 1657 & 39.9 & 1060 & 597 \\
\hline A. mitchilli & 900 & 21.7 & 431 & 135 \\
\hline M. undulatus & 410 & 9.9 & 145 & 275 \\
\hline M. martinica & 236 & 5.7 & 73 & 153 \\
\hline A.felis & 227 & 5.5 & 66 & 96 \\
\hline Penaeid shrimp & 162 & 5.0 & 37 & 54 \\
\hline M. americanus & 91 & 2.2 & 57 & 32 \\
\hline C. nebulosus & 89 & 2.1 & 37 & 45 \\
\hline L. xanthurus & 82 & 2.0 & 27 & 25 \\
\hline C. arenarius & 52 & 1.3 & 43 & 864 \\
\hline B. chrysoura & 51 & 1.2 & 2111 & 1845 \\
\hline TOTAL & 3957 & 94.5 & & \\
\hline
\end{tabular}

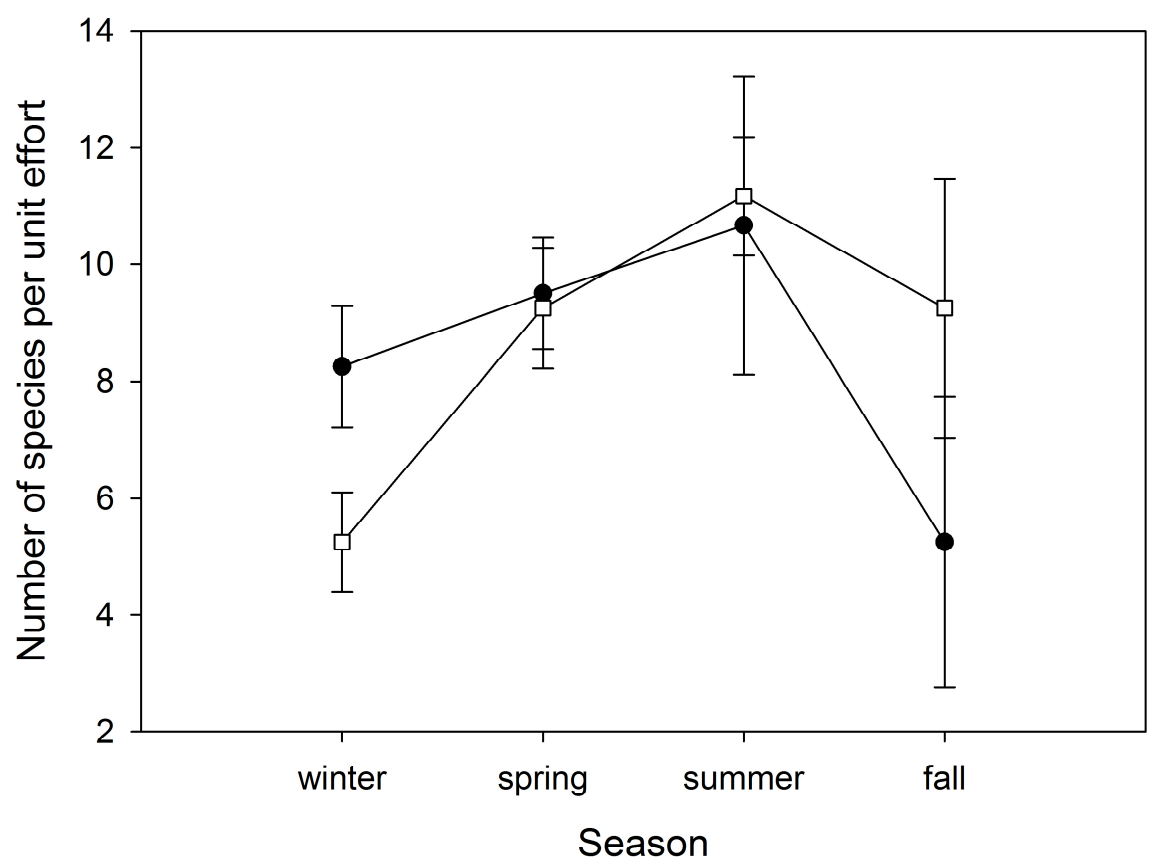

Fig. (3). Mean species richness by season at artificial reef and mud-bottom habitats in Barataria Bay, Louisiana. Black circles represent artificial reef samples. White squares represent mud-bottom site samples. Standard error bars are shown.

2.05 to $9.75 \mathrm{mg} \mathrm{l}^{-1}$ over the reef and 2.12 to $10.12 \mathrm{mg} \mathrm{l}^{-1}$ over the mud bottom site (Fig. 2). Only temperature differed significantly among seasons $(\mathrm{p}<0.0001$, ANOVA).

A total of 4,149 fishes were collected with the 11 most frequently caught species making up $95 \%$ of the catch in numbers (Table 1). Forty-six taxa were collected, including forty-three finfish and three shrimp species. Gulf menhaden and bay anchovy were most abundant, making up $40 \%$ and $22 \%$ of the catch, respectively. Thirty-eight species of fish and invertebrates were collected over the artificial reef, while thirty-four species were collected over the mud bottom site. Twelve species were found exclusively over the reef and eight were collected exclusively over the mud bottom site. These twenty species were all found relatively infrequently, making up only $1.1 \%$ of the total catch. The mean of species richness (in number of species per set) ranged from $5.25 \pm$ 2.49 to $10.67 \pm 2.55$ at the reef site and $5.25 \pm 0.85$ to 11.17 \pm 1.01 at the mud bottom site. There were no significant differences in mean of species richness between habitats or among seasons ( $p>0.05$, ANOVA) (Fig. 3). 

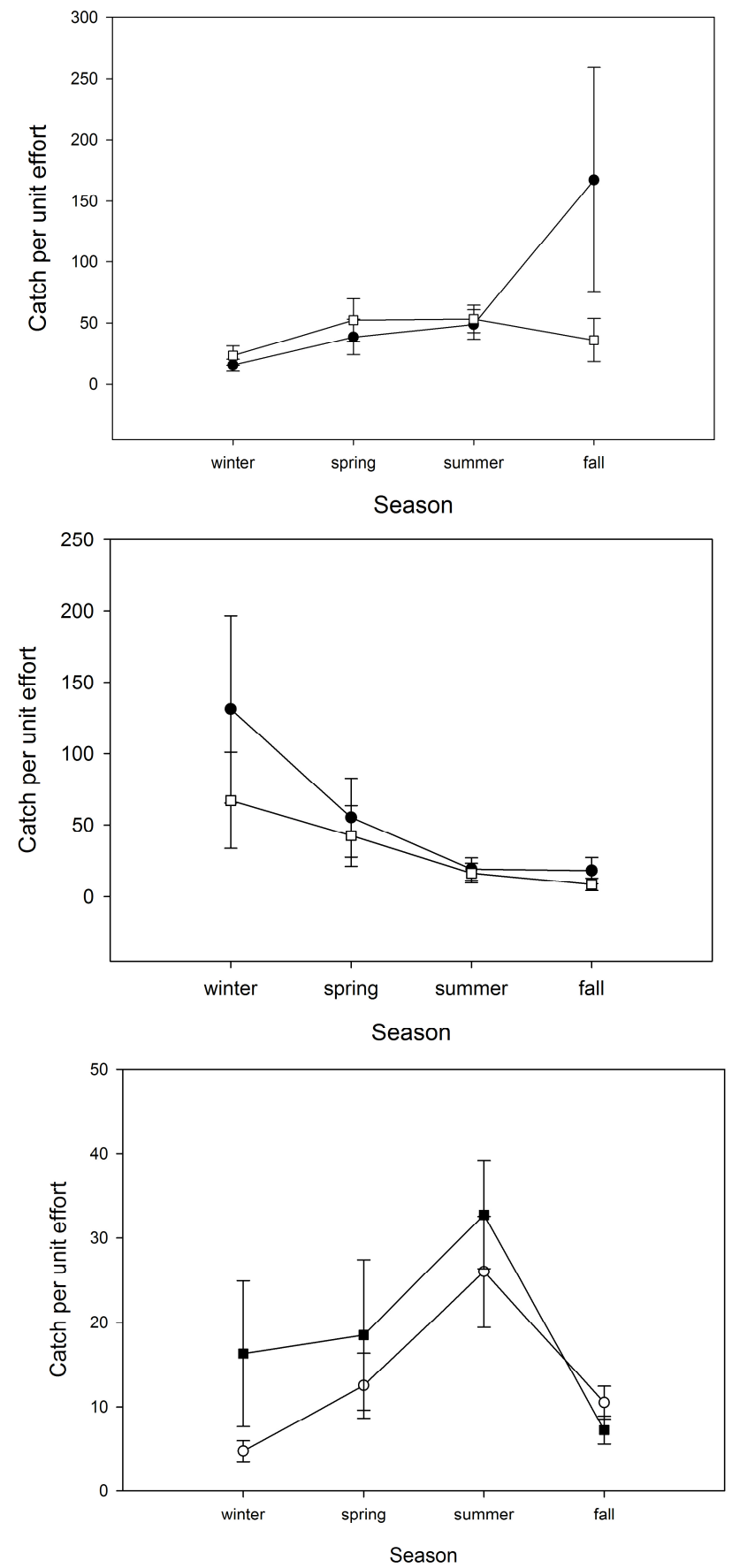

Fig. (4). Mean catch per unit effort (CPUE) of gillnets (top), gills nets without Gulf menhaden (Brevoortia patronus) (middle) and purse seine (bottom) samples over seasons at artificial reef and mud-bottom habitats in Barataria Bay, Louisiana. Black circles represent artificial reef samples and white squares represent mudbottom site samples. Bars represent standard error.

Community structure did not differ between habitats $(\mathrm{p}>$ 0.05 , ANOSIM), as the most commonly observed species were present at both site, though there were seasonal differences in community structure ( $p<0.05$, ANOSIM). Gulf menhaden was the most abundant species pooled over all seasons and was present in high abundances all year. Spring samples were characterized by high abundances of Gulf menhaden, bay anchovy, and Atlantic croaker. Summer samples resulted in high abundances of rough silversides (Membras martinica), hardhead catfish, and Gulf menhaden. Fall and winter samples both showed high abundances of Gulf menhaden, rough silversides, bay anchovy, and hardhead catfish. Abundances of spotted seatrout were similar in the spring and summer and low in the fall and winter, while Atlantic croaker had highest abundances in spring.

Mean of CPUE, mean of CPUE excluding menhaden, and the mean of CPUE for the purse seine did not differ between habitats ( $p>0.05$, ANOVA). Seasonal differences were observed for gillnet catches, both including and excluding Gulf menhaden ( $<<0.05$, ANOVA). Mean CPUE for total gillnet catches was significantly higher for fall samples as compared to winter samples, and catches excluding Gulf menhaden were significantly different among summer, fall, and winter (Fig. 4). Tukey HSD post-ANOVA pairwise testing excluding Gulf menhaden revealed that summer CPUE was significantly higher than winter CPUE (Fig. 4). Pairwise tests of fishes collected by purse seine confirm that winter CPUE was significantly higher than CPUE in all other seasons (Fig. 4).

Nearly twice as many spotted seatrout were collected at the artificial reef (Table 1), however catch totals based on CPUE were not significantly different between habitats $(\mathrm{p}=$ 0.11 , ANOVA). There were seasonal differences in CPUE of spotted seatrout $(p<0.05$, ANOVA) with pairwise tests revealing that summer CPUE was significantly higher than winter and fall catches (Fig. 5). The interaction between site and season was not significant ( $p>0.05$, ANOVA). The probability of presence of spotted seatrout was not dependent upon site (logistic regression; $\mathrm{p}=0.14$ ), but was dependent both upon water temperature and salinity $(\mathrm{p}<0.05$, logistic regression).

Twice as many Atlantic croaker were collected at the mud bottom site (Table 1), however catch totals based on CPUE were also not significantly different $(\mathrm{p}>0.05$, ANOVA). Seasonal differences in CPUE of Atlantic croaker were observed, $(p<0.05$, ANOVA) with pairwise tests revealing that spring and summer CPUE was higher than that in winter (Fig. 5). The interaction between site and season was not significant for Atlantic croaker. The probability of presence of Atlantic croaker was not dependent upon habitat, water temperature or salinity ( $p>0.05$, logistic regression).

Catches of bay anchovy were equivalent between habitats, and CPUE was not significantly different between habitats (Table 1; p > 0.05, ANOVA). There were significant seasonal differences in abundance of bay anchovy, with post-hoc tests indicating that CPUE of bay anchovy was higher in the winter than in other seasons (Fig. 5). There was a significant interaction between site and season for bay anchovy $(p=0.07)$. The probability of presence of bay anchovy was not dependent upon habitat, water temperature, or salinity (logistic regression; $p>0.05$ ).

Significant differences were observed in the SL and wet weight of spotted seatrout, Atlantic croaker, and bay anchovy between habitats. Spotted seatrout were significantly larger over the reef site $(\mathrm{p}<0.0001$, ANOVA), with a mean $\mathrm{SL}$ of $305 \pm 6.9 \mathrm{~mm}$ over the reef and $243 \pm 10.1 \mathrm{~mm}$ over the mud bottom site. The mean wet weight of spotted sea 

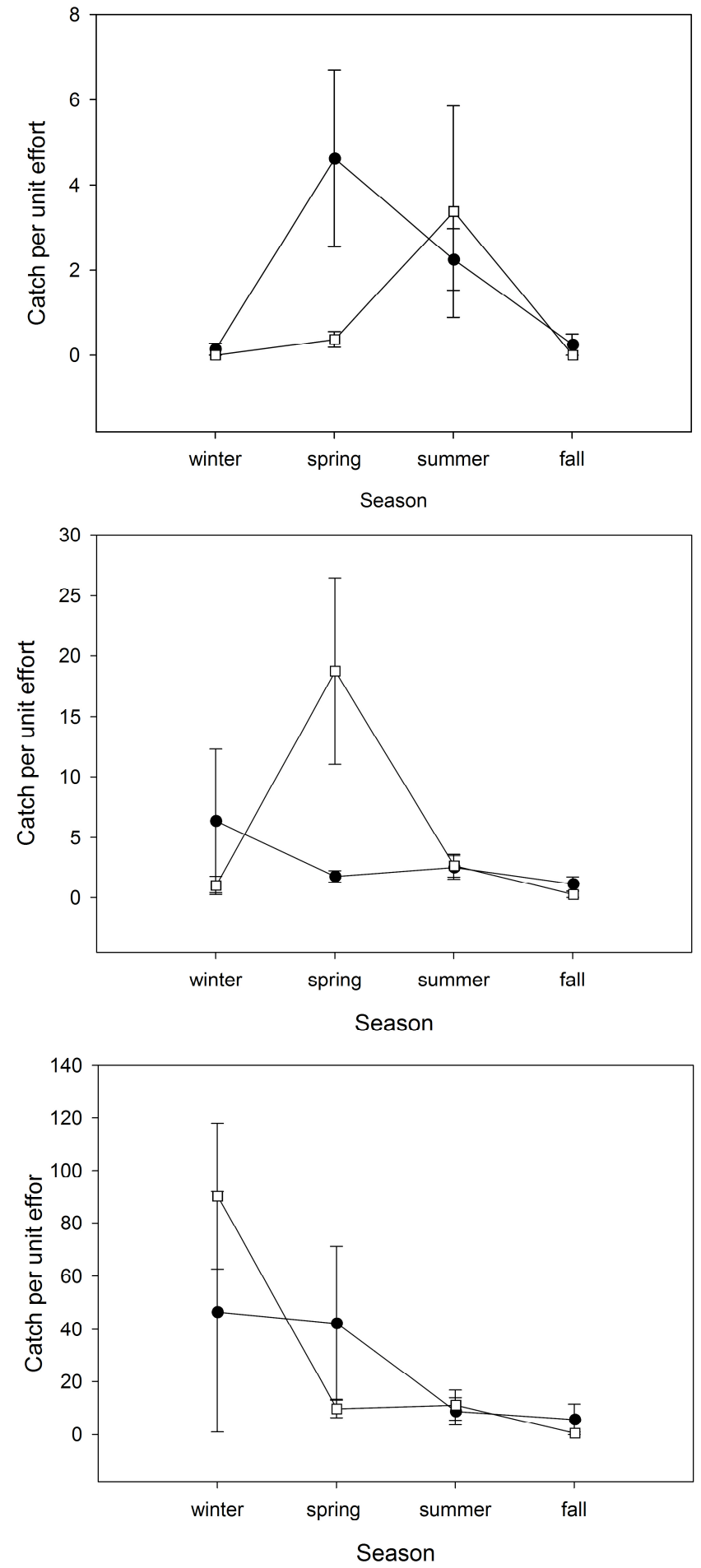

Fig. (5). Mean catch per unit effort (CPUE) of spotted seatrout (Cynoscion nebulosus) (top), Atlantic croaker (Micropogonias undulatus) (middle), and bay anchovy (Anchoa mitchilli) (bottom) over seasons at artificial reef and mud-bottom habitats in Barataria Bay, Louisiana. Black circles represent artificial reef samples and white squares represent mud-bottom site samples. Bars represent standard error.

trout was $435.3 \pm 28.5 \mathrm{~g}$ and $233.5 \pm 24.4 \mathrm{~g}$ over the reef and mud bottom sites, respectively (Fig. 6). Atlantic croaker also were significantly larger over the artificial reef $(p<0.0001$, ANOVA), with a mean SL of $83 \pm 3.7 \mathrm{~mm}$ over the reef and
$77 \pm 0.9 \mathrm{~mm}$ over the mud bottom site (Fig. 6). The mean wet weight of croaker was significantly different, with a mean of $19.8 \pm 2.1 \mathrm{~g}$ over the reef as compared to $9.9 \pm 0.5 \mathrm{~g}$ over the mud bottom site $(\mathrm{p}<0.0001)$. Bay anchovy were significantly larger over the mud bottom site $(p<0.001$, ANOVA), with a mean SL of $45 \pm 0.4 \mathrm{~mm}$ over the reef as compared to $47 \pm 0.5 \mathrm{~mm}$ over the mud bottom site (Fig. 6). Mean wet weights of bay anchovy were also significantly different between habitats with a mean of $1.2 \pm 0.04 \mathrm{~g}$ over the reef as compared to $1.4 \pm 0.05 \mathrm{~g}$ over the mud bottom site $(\mathrm{p}<0.001$, ANOVA). Tukey post-hoc tests confirmed all differences in sizes between habitats for the three species examined. Taken together with the CPUE data, results indicate there is a higher biomass of both spotted seatrout and Atlantic croaker over the artificial reef site $(\mathrm{p}<0.05$, ANOVA). There were no significant differences in biomass of bay anchovy between habitats $(p>0.05)$.

\section{DISCUSSION}

One thing that is important to consider in the context of habitat alteration projects, is what the overall objective the project will be. Different user groups (i.e. commercial fisherman, environmental groups, scientists, etc.) may view success differently, depending on how they assign value to a particular habitat [19]. Therefore, it is important to consider whether a habitat alteration is intended to benefit the ecosystem on a community-wide basis, or whether it is designed to support one species in particular.

The estuarine fish community in Barataria Bay showed no distinct differences in species richness between the artificial reef site and the mud bottom site. The dominant species collected were found in high abundances over both habitats. Those species that were collected solely at one site were found too infrequently ( 3 individuals or fewer) to influence comparison of overall community structure. There were also no differences in overall abundances of fishes between habitats. These results are consistent with other studies in Barataria Bay by Plunket and LaPeyre [29] and MacRae [30], who also found no differences in either species richness or species abundance between oyster reef habitat and mudbottom habitat. A similar study by Harding and Mann [3] on transient fish species in Chesapeake Bay found no sitespecific linkages based on habitat. Other studies have concluded that a large and diverse fish community can regularly be observed in the vicinity of natural and restored oyster reefs [21, and mud bottoms therein, 31, 32]. These studies provide evidence that many species may opportunistically use different habitat types for foraging, spawning, or predator avoidance.

Nearly twice as many spotted seatrout were collected over the artificial reef, and these fish were roughly $20 \%$ larger than those collected over the mud bottom, indicating the artificial reef supports a higher biomass of spotted seatrout. While spotted seatrout were larger at the reef, abundance as not difference between habitats, which is similar to results found be MacRae and Cowan [33], and indicates that seasonal influences have a more pronounced effect on the distribution of spotted seatrout than the presence of reef structure. Specifically, spotted seatrout were affected by temperature and salinity, and presence was determined more 

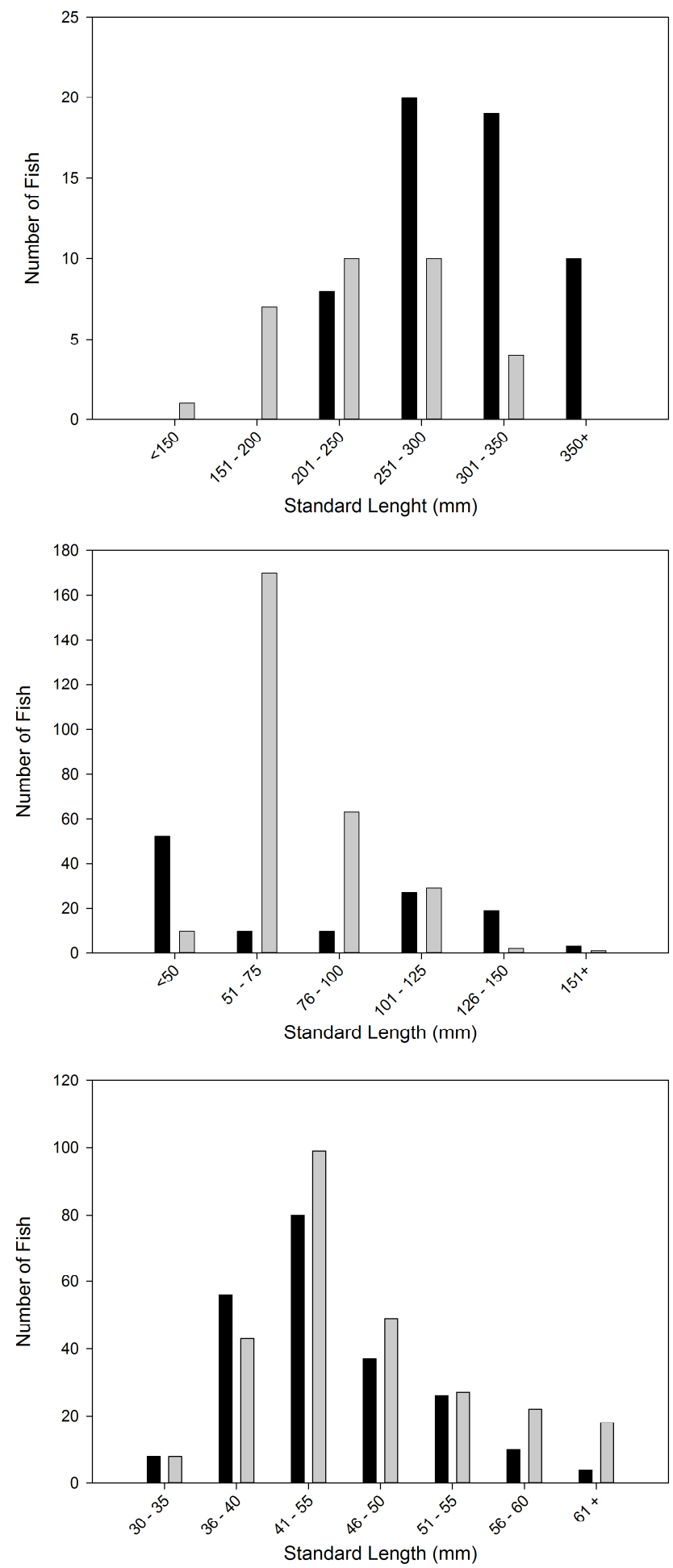

Fig. (6). Size frequency distribution of spotted seatrout (Cynoscion nebulosus) (top), Atlantic croaker (Micropogonias undulatus) (middle), and bay anchovy (Anchoa mitchilli) (bottom) at artificial reef and mud-bottom habitats in Barataria Bay, Louisiana. Black bars represent artificial reef samples. Grey bars represent mud-bottom site samples.

by these two factors than by the habitat. This result is consistent with the findings of MacRae and Cowan [33] and to a study of acoustically tagged spotted seatrout by Callihan [34], found strong responses of spotted seatrout to low salin- ity events, and seasonal preferences for reef (both natural and artificial) habitats. Callihan [34] observed that spotted seatrout were frequently located near reef habitats in the spring and summer months, though this research is still ongoing. We cannot rule out the possibility that they were similarly abundant in every season. In a study of spotted seatrout movement in Lake Calcasieu, Louisiana, it was observed that acoustically tagged fish moved much greater distances in warmer months, but moved very little in cold months, sometimes staying in the same area for up to a week at a time (J. Callihan, NC State University, personal communication). Because gillnets are passive, it may be that variability in activity owing to temperature effects on feeding and respiration could have influenced our results. In addition, spotted seatrout are known both to feed opportunistically and to have relatively low site fidelity, therefore the most important aspect of a habitat for such a species may be the availability of prey. Harding and Mann concluded that an increased abundance of bluefish (Pomatomus saltatrix) [35] and striped bass (Morone saxatilis) [36] over living oyster reefs was likely due to the increased availability of prey, especially fishes.

Atlantic croaker is known to be one of the most ubiquitous species in the northern Gulf of Mexico, especially during early life. It has been collected from a large variety of habitat types, although it appears to be best adapted for foraging on soft-bottom [37]. While there were no significant differences in abundances of Atlantic croaker between habitats, there was significantly higher biomass of Atlantic croaker over the reef and significantly larger Atlantic croaker were collected over the reef. Previous studies on the abundances of Atlantic croaker among different habitats have had conflicting results. Harding and Mann [3] collected Atlantic croaker consistently over all bottom types, but found higher overall abundances of Atlantic croaker over a restored oyster reef in Chesapeake Bay. Other studies have indicated that Atlantic croaker utilize oyster reef habitat frequently as a foraging ground [21, 38]. However, Petrik et al. [39] found no effect of habitat on numbers of newly recruited Atlantic croaker in a Texas estuary.

Bay anchovy is a transient schooling species that generally does not associate with any single type of habitat, and was found in relatively equal numbers between habitats in the current study. Minello [12], and Stunz et al. [40] found high numbers of bay anchovy over shallow, non-vegetated habitat and along marsh edge habitat, but relatively few individuals over oyster reefs in Texas and Louisiana. Alternatively, a review by Coen et al. [21] reported bay anchovy to be associated with oyster reefs in Virginia, South Carolina, and Texas. In contrast, results of this study indicate that bay anchovy abundance, biomass, and CPUE did not differ between habitats. Bay anchovy is one of the most abundant fish species in the northern Gulf of Mexico and is ubiquitous in Louisiana's estuaries. As such, it is likely that the presence of reef habitat did not affect the presence of bay anchovy. However, higher numbers of bay anchovy were found in the stomachs of spotted seatrout captured over the reef in this study [41], a result that is similar to the study by Harding and Mann [35] on bluefish.

It is important to note that no attempt was made to capture small, cryptic, benthic fish species, many of which are 
considered oyster reef residents, as this study was designed to focus on recreationally important fish species. It is also important to note that the artificial reef was built in 2004, immediately prior to the initiation of the sampling effort. Many of the reefs examined in a review by Coen et al. [21] and studies by Harding and Mann [3, 35, 36, 38] were constructed years before the initiation of sampling. Artificial reefs progress through a succession with initial rapid appearance of transient species, followed by establishment of reefassociated species, and finally colonization of reef-dependent fish and invertebrate species [10, 42, 43]. A reef is considered "established" when it reaches the equilibrium phase of a stable community structure. It is possible that the artificial reef examined here had not had enough time to become established and as such does not support a "climax" reef community.

Storm events have been shown to reset artificial reef systems by both scouring the reef material and by causing dispersal of reef-associated species [43]. Shortly after sampling began for this study, two major hurricanes (winds $>120 \mathrm{kts}$ ) affected both habitats in less than a month. The passage of these storms undoubtedly scoured the reef and removed both fishes and invertebrates. In addition to tropical storm systems, the area is regularly subjected to strong winter winds that can have similar, though less severe, effects. Frequent disturbances may prevent the colonization of reef dependent specialists and may make the habitat more suitable for opportunistic and generalist strategists [44]. Gregalis et al. [10] reported similar results from a series of reefs created in Mobile Bay, Alabama. The dynamic environment in which this artificial reef was constructed may prevent the system from ever reaching a climax reef community, but instead allow it to support a community of opportunistic species [10].

Our research indicates that the presence of an artificial reef had negligible effects on the estuarine fish community structure as species richness and abundance of most species did not differ between habitats. The few differences observed were most likely attributable to seasonal variability. The only species that seemed to be positively affected by the presence of the reef was spotted seatrout, with significantly higher biomass over the artificial reef site. This is important because spotted seatrout are a major component of the recreational fishery in Louisiana, with a harvest of over 11 million pounds in 2008 [45]. As a habitat enhancement project designed to either increase fishing opportunities or enhance a specific fishery (spotted seatrout), this study can be looked at as a success. However, in the context of habitat restoration and ecosystem-wide function, there was no increase in abundance of most other species. Therefore, it is important to understand the purpose, placement, and function of habitat additions, and whether the goal is either fishery enhancement or habitat restoration. The results can be very different depending on the question asked and whether or not the project is designed for either overall ecosystem enhancement or for the benefit of a particular fishery.

\section{CONFLICT OF INTEREST}

The authors confirm that this article content has no conflicts of interest.

\section{ACKNOWLEDGEMENTS}

We would like to thank Michelle Zapp Sluis and David Nieland for assistance in the field and in the laboratory. Field sampling would not have been possible without the help of personnel from the Louisiana Department of Wildlife and Fisheries Lyle St. Amant Marine Biological Laboratory. We would especially like to thank Randy Pausina and Jason Adriance for all the time and help to coordinate field sampling. Early versions of this work benefitted from the comments of David Nieland as well as three anonymous reviewers. This project was funded by the Louisiana Department of Wildlife and Fisheries with Sport Fish Restoration dollars provided through the U.S. Fish and Wildlife Federal Assistance Program.

\section{REFERENCES}

[1] Caddy JF. Marine habitat and cover. Their importance for productive coastal fishery resources. Paris, France: UNESCO Publishing 2007; p.253.

[2] Marasco RJ, Goodman D, Grimes CB, Lawson PW, Punt AE, Quinn III TJ. Ecosystem-based fisheries management: some practical suggestions. Can J Fish Aquat Sci 2007; 64: 928-39.

[3] Harding JM, Mann R. Oyster reefs as fish habitat: opportunistic use of the restored reefs by transient fishes. J Shellfish Res 2001a; 20: 951-9.

[4] Luckenbach MW, Coen LD, Ross PG, Stephen JA. Oyster reef habitat restoration: relationships between oyster abundance and community development based on two studies in Virginia and South Carolina. J Coast Res 2005; SI-40: 64-78.

[5] Reed DC, Schroeter SC, Huang D, Anderson TW, Ambrose RF. Quantitative assessment of different artificial reef designs in mitigating losses to kelp forest fishes. Bull Mar Sci 2006; 78: 133-50.

[6] Tallman JC, Forrester GE. Oyster grow-out cages function as artificial reefs for temperate fishes. Trans Am Fish Soc 2007; 136: 790-9.

[7] Bohnsack JA. Are high densities of fishes at artificial reefs the result of habitat limitation or behavioral preference? Bull Mar Sci 1989; 44: 631-45.

[8] Stanley DR, Wilson CA. Variation in the density and species composition of fishes associated with three petroleum platforms using dual beam hydroacoustics. Fish Res 2000; 47: 161-72.

[9] Stanley DR, Wilson CA. Seasonal and spatial variation in the biomass and size frequency distribution of fish associated with oil and gas platforms in the northern Gulf of Mexico. AFS Symposium 36, Bethesda MD, 2003; pp.123-53.

[10] Gregalis KC, Johnson MW, Powers SP. Restored oyster reef location and design affect responses of resident and transient fish, crab, and shellfish species in Mobile Bay, Alabama. Trans Am Fish Soc 2009; 138: 314-27.

[11] Baltz DM, Rakocinski CF, Fleeger JW. Microhabitat use by marshedge fishes in a Louisiana estuary. Environ Biol Fish 1993; 36:10926.

[12] Minello TJ. Nekton densities in shallow estuarine habitats of Texas and Louisiana and the identification of Essential Fish Habitat." AFS Symposium 22, Bethesida MD, 1999; pp. 43-75.

[13] Day Jr. JW, Boesch DF, Clairain EJ, et al. Restoration of the Mississippi delta: lessons from hurricanes Katrina and Rita. Science 2007; 23:1679-84.

[14] Brander LM, Florax RJG, Vermaat JE. The empirics of wetland valuation: a comprehensive summary and a meta-analyses of the literature. Environ Resour Econ 2006; 33: 223-50.

[15] Nyman JA, LaPeyre MK, Caldwell A, Piazza S, Thom C, Winslow C. Defining restoration targets for water depth and sailinity in wind-dominated Spartina patens (Ait.) Muhl. coastal marshes. J Hydrol 2009; 376: 327-36.

[16] Williams SJ, Stone GW, Burruss AE. A perspective on the Louisiana wetland loss and coastal erosion problem. J Coast Res 1997; 13: 593-4.

[17] Couvillion BR, Barras JA, Steyer GD, et al. Land area change in coastal Louisiana from 1932 to 2010, U.S. Geological Survey Sci- 
entific Investigations Map 3164 2011; scale 1: 265,000. p.12 Pamphlet, 2011.

[18] Piazza BP, Banks PD, LaPeyre MK. The potential for created oyster shell reefs as a sustainable shoreline protection strategy in Louisiana. Restor Ecol 2005; 13(3): 499-506.

[19] LaPeyre MK, Nix A, Laborde L, Piazza BP. Gauging state-level and user group views of oyster reef restoration activities in the northern Gulf of Mexico. Ocean Coast Manag 2012; 67: 1-8.

[20] Lenihan HS, Peterson CH. How habitat degradation through fishery disturbance enhances impacts of hypoxia on oyster reefs. Ecol Appl 1998; 8:128-40.

[21] Coen LD, Luckenbach MW, Breitburg DL. The role of oyster reefs as Essential Fish Habitat: a review of current knowledge and some new perspectives. AFS Symposium 22, Bethesida MD, 1999; pp. 438-54.

[22] Lenihan HS, Peterson CH, Byers JE, Grabowski J, Thayer GW, Colby DR. Cascading of habitat degradation: oyster reefs invaded by refugee fishes escaping stress. Ecol Appl 2001; 11: 764-82.

[23] Haywood EL III, Soniat TM, Broadhurst III RC. In: Luckenbach MW, Mann R, Wesson JA, Eds. Oyster reef habitat restoration: a synopsis and synthesis of approaches. Gloucester Point, Virginia: Virginia Institute of Marine Science Press 1999; pp. 295-304.

[24] Breitburg D. Are three dimensional structure and healthy oyster populations the keys to an ecologically interesting and important fish community. In: Luckenbach MW, Mann R, Wesson JA, Eds. Oyster reef habitat restoration: a synopsis and synthesis of approaches. Virginia: Virginia Institute of Marine Science Press, Gloucester Point, 1999; pp. 239-50.

[25] Luckenbach MW, Mann R, Wesson JA, Eds. Louisiana Department of Wildlife and Fisheries (LDWF). Oyster stock assessment report of the public oyster areas in Louisiana. Oyster Data Report Series No. 17.USA: Marien Fishries Division. 2011; pp. 92.

[26] Lindberg WJ, Frazer TK, Portier KM, et al. Density-dependent habitat selection and performance by a large mobile reef fish. Ecol Appl 2006; 16(2): 731-6.

[27] SAS Institute Inc. Version 9.2. Cary, North Carolina, USA. 2010.

[28] Clarke KR, Warwick RM. Change in marine communities: an approach to statistical analysis and interpretation. $2^{\text {nd }}$ ed. Plymouth, United Kingdom: PRIMER-E Ltd., 2001.

[29] Plunket JT, LaPeyre MK. Oyster beds as fish and macroinvertebrate habitat in Barataria Bay, Louisiana. Bull Mar Sci 2005; 77:155-64

[30] MacRae PSD. A community approach to indentifying essential fish habitat of spotted seatrout, Cynoscion nebulosus, in Barataria Bay, Louisiana. Ph.D dissertation. Baton Rouge, Louisiana, USA: Louisiana State University 2006; p. 161.

[31] Quan WM, Zhu JX, Ni Y, Shi LY, Chen YQ. Faunal utilization of constructed intertidal oyster (Crassostrea rivularis) reef in the Yangtze River estuary, China. Ecol Eng 2009; 35: 1466-75.
[32] Humphries AT, LaPeyre MK, Kimball ME, Rozas LP. Testing the effect of habitat structure and complexity on nekton assemblages using experimental oyster reefs. J Exp Mar Biol Ecol 2011; 409: 172-9.

[33] MacRae PSD, Cowan Jr. JH. Habitat preference of spotted seatrout, Cynoscion nebulosus, in coastal Louisiana: A step towards informing spatial management in estuarine ecosystem. Open Fish Sci J 2010; 3: $154-63$.

[34] Callihan JL. Spatial ecology of adult spotted seatrout, Cynoscion nebulosus, in Louisiana coastal waters. Ph.D. dissertation. Baton Rouge, Louisiana, USA: Louisiana State University 2011; p.296.

[35] Harding JM, Mann R. Fish species richness in relation to restored oyster reefs, Piankatank River, Virginia. Bull Mar Sci 1999; 61: 289-300.

[36] Harding JM, Mann R. Diet and habitat use by bluefish, Pomatomus saltatrix, in a Chesapeake Bay estuary. Environ Biol Fish 2001b; 60: 401-9.

[37] Overstreet RM, Heard RW. Food of the Atlantic croaker, Micropogonias undulatus, from Mississippi Sound and the Gulf of Mexico. Gulf Res Rep 1978; 6:145-52.

[38] Harding JM, Mann R. Influence of habitat on diet and distribution of striped bass (Morone saxatilis) in a temperate estuary. Bull Mar Sci 2003; 72: 841-5.

[39] Petrik R, Levin PS, Stunz GW, Malone J. Recruitment of Atlantic Croaker, Micropogonias undulatus: do postsettlement processes disrupt or reinforce initial patterns of settlement? Fish Bull 1999; 97: 954-61.

[40] Stunz GW, Minello TJ, Rozas LP. Relative value of oyster reef as habitat for estuarine nekton in Galveston Bay, Texas. Mar Ecol Prog Ser 2010; 406: 147-59.

[41] Simonsen KA, Cowan JH Jr. Effects of an inshore artificial reef on the trophic dynamics of three species of estuarine fish. Bull Mar Sci 2013; 89(3): 657-76.

[42] Bohnsack JA, Harper DE, McClellan DB, Hulsbeck M. Effects of reef size on colonization and assemblage structure of fishes at artificial reefs off southeastern Florida, USA. Bull Mar Sci 1994; 55: 796-823.

[43] Cummings S. Colonization of a nearshore artificial reef at Boca Raton (Palm Beach County), Florida. Bull Mar Sci 1994; 22:1193215.

[44] Wilson SK, Burgess SC, Cheal AJ, et al. Habitat utilization by coral reef fish: implications for specialists vs. generalists in a changing environment. J Anim Ecol 2008; 77: 220-8.

[45] NMFS Recreational Fishery Statistics. Available from: http://www.st.nmfs.noaa.gov/st1/recreational/queries/catch/time_se ries.html

(C) Simonsen et al.; Licensee Bentham Open.

This is an open access article licensed under the terms of the Creative Commons Attribution Non-Commercial License (http://creativecommons.org/licenses/ by-nc/3.0/) which permits unrestricted, non-commercial use, distribution and reproduction in any medium, provided the work is properly cited. 